\title{
China's Regulatory Framework for Outward Foreign Direct Investment
}

\author{
22 February 2014
}

\author{
Karl P. Sauvant, $\mathrm{PhD}$ (corresponding author) \\ Resident Senior Fellow and Founding Executive Director \\ Vale Columbia Center on Sustainable International Investment \\ Columbia Law School - The Earth Institute \\ Columbia University \\ 435 W $116^{\text {th }}$ St., Rm. 645, New York, N.Y.,10027, USA \\ Tel. 1914437 5668; Email: karlsauvant@gmail.com \\ Victor Zitian Chen, $\mathrm{PhD}$ \\ Assistant Professor of International Management \\ Belk College of Business \\ University of North Carolina, Charlotte \\ and \\ EMGP Global Coordinator and Editor \\ Vale Columbia Center on Sustainable International Investment \\ Columbia Law School - The Earth Institute \\ Columbia University \\ 240C - Friday Building, 9201 University City Blvd \\ Charlotte, NC, 28223-0001 \\ Tel: 1980636 9207; Email: EMGP.Editor@gmail.com
}

The final version was published in the China Economic Journal, 7(1) (2014), pp. 141-163.

\begin{abstract}
China has become the world's third largest outward investor, behind the United States and Japan. A growing body of literature suggests that China's regulatory framework for outward foreign direct investment (OFDI) is a determinant of the country's rising OFDI. This paper presents a holistic review of that framework, including some possibilities for its improvement. Overall, China's framework serves two objectives: to help Chinese firms become more competitive internationally and to assist the country in its development effort. In pursuing these objectives, the regulatory framework has moved from restricting, to facilitating, to supporting, to encouraging OFDI; but there are still strong elements of administrative control that make it cumbersome. State-owned enterprises (SOEs) seem to benefit particularly from the current framework when internationalizing through FDI.
\end{abstract}

Keywords: China, outward foreign direct investment, OFDI, formal institutions, government. JEL Codes: F21, F23, F31, F65, G18, G28, G38, H1, H2, H3, K2, K3, M16, P33.

\section{Acknowledgements}

The authors gratefully acknowledge the support of the East Asian Bureau of Economic Research (EABER) in the Crawford School of Public Policy at the Australian National University. They benefitted greatly from the discussions at the EABER Roundtable for which this paper was prepared and at a roundtable at the 2013 Academy of International Business meeting in Istanbul, Turkey. They also acknowledge important help from Bekele Amare, Mark Feldman, Shuang Liu, Wouter Schmit Jongbloed, Bijun Wang, Yuanyuan Xiu, and Kenny K. Zhang, as well as helpful feedback from Vivienne Bath, Kim Fahem, Chris Fraser, Jane Golley, Thilo Hanemann, Victor Hu, Zhongmin Li, Hao Liang, Bing Ren, Xiaofang Shen, Valentina Valdi, Hinrich Voss, Lisa Mei Wei, Lutz-Christian Wolff, Stephen Wortley, Yuen Pau Woo, Daying Yan, and Ying Zheng. Special thanks to the Asia Pacific Foundation of Canada for kindly sharing CCPIT's raw 
survey data. Thanks go also to Levon Golendukhin, Sara Hambright and Jon-David Jorgensen for their research assistance. Any errors or omissions are of course those of the authors.

\section{Introduction}

For the first time ever, in 2012 China became the world's third largest outward investor, with US\$84 billion outward foreign direct investment (OFDI) flows, following the United States (US\$329 billion) and Japan (US\$123 billion) (United Nations Conference on Trade and Development [UNCTAD] 2013a, 6, 213). A growing literature suggests that China's regulatory framework for OFDI, notably government policies, laws and regulations, is a determinant of the country's growing investment outflows (see, e.g., Buckley et al. 2008; Cui and Jiang 2012; Luo, Xue, and Han 2010). However, few efforts have been made so far to provide a holistic picture of this framework in the context of the country's 'go out' strategy. ${ }^{1}$ This paper reviews the country's major policies, laws, and regulations that relate to OFDI to discuss why and how the government is helping Chinese firms to invest abroad.

\section{The Regulatory Framework: from Restricting, to Facilitating, to Supporting, to Encouraging OFDI}

The overall objective of China's current regulatory framework for OFDI is twofold. First, the framework seeks to facilitate and support OFDI in order to nurture globally competitive Chinese firms. This objective, in turn, is the result of an interplay of two factors. The first factor is the government's desire to have internationally competitive firms whose portfolio of locational assets provides better access to markets and resources (natural, strategic and other resources) and which itself becomes a source of corporate competitiveness. The second factor is the pressure on government by firms that seek to internationalize in response to domestic and international competition. Formal fora in which firms can make themselves heard and exercise pressure on government policies include the National People's Congress (NPC) and the Chinese People's Political Consultative Conference (CPCCC). For instance, during the 2013 NPC and CPCCC sessions, a Senior Vice President of Midea Group called for more reform and policy innovation to provide broader support (e.g., finance, technology, fiscal policy, human resource development) for Chinese companies going abroad ('Outward FDI chapter' 2013). Other major representatives of the business elite such as Dongsheng Li, President of TCL, and Shufu Li, President of Zhejiang Geely Group, also encouraged the government to liberalize its OFDI review process and provide more resources and information to support OFDI ('Outward FDI chapter' 2013). Deming Chen, the Minister of Commerce at the time, responded that China's approval process has thus far focused only on the direction and amount of OFDI, but would inevitably become less cumbersome ('Outward FDI chapter' 2013).

\footnotetext{
${ }^{1}$ Although the expression 'go out' policy is usually used as the official translation of 走出去战略 (see, e.g., Government of China [2006]), 'going out', 'go abroad', 'going abroad', 'step out', and 'stepping out' are sometimes used interchangeably in the literature.
} 
Second, China's institutional framework for OFDI especially seeks to encourage OFDI that can contribute most to the country's national development. It does this by selectively supporting particular industries and activities in their internationalization through FDI. For the national economy, broadening the scope and geography of investment means more options for economic (re)structuring (e.g., value-chain upgrading and integration) and resource allocation optimization (e.g., reducing the cost of raw materials and labor); OFDI thus provides more resources and opportunities for economic growth (Chen 2009). In addition, OFDI provides access to tangible and intangible resources that are of direct relevance to China's development effort, beginning with raw materials but also including technology, brand names etcetera. This development objective is reflected in the fact that OFDI is encouraged by the government through various instruments (discussed below) in particular industries and activities that are of special importance to the development effort.

These two objectives evolved from a series of previous government pronouncements and policy documents. Most important among them was the formalization, during the Third Plenum of the Ninth National People's Congress in March 2000 (Yu and Jiao 2011), of the country's 'go out' strategy in the $10^{\text {th }}$ Five-Year Plan on Economic and Social Development (hereafter the $10^{\text {th }}$ Five-Year Plan) (NPC 2001). The $10^{\text {th }}$ Five-Year Plan explained the strategy as a means to 'to encourage OFDI into areas where China has competitive advantages, and to expand the scope, channels and modes of international economic and technological cooperation' (NPC 2001).

As part of the $10^{\text {th }}$ Five-Year Plan, the $10^{\text {th }}$ Five-Year Plan on Inward and Outward FDI (hereafter the $10^{\text {th }}$ FDI Five-Year Plan) was released by the then State Planning Commission (SPC) on 24 December 2001. The latter document more explicitly elaborated that the objective of the 'go out' strategy was to: actively and stably expand investment overseas; facilitate strategic investment by capable firms in natural resources exploration and other areas in which Chinese firms hold a comparative advantage; and develop internationally competitive multinational enterprises (MNEs) (NDRC 2001). By this time, both purposes discussed earlier - i.e., to facilitate Chinese OFDI in order to nurture the international competitiveness of Chinese firms, and to use OFDI for China's overall development - had been clearly formulated.

These two objectives were elaborated on again in a number of subsequent policy documents guiding OFDI. The most general and authoritative guiding policy was set out in the State Council's Opinions on Encouraging and Guiding Foreign Investment and Cooperation by Chinese Enterprises (hereafter the 2006 Opinions) (State Council 2006). It reiterated the objectives of the country's OFDI strategy, viz. to:

- more effectively utilize two types of resources and two markets (i.e., domestic and international);

- facilitate the structural adjustment of the economy;

- enhance the international competitiveness of Chinese firms;

- promote cooperation with OFDI partner countries; and 
- promote the development of China (and that of the partner countries) (State Council 2006).

These objectives were very similar to those specified in the Outward Investment Sector Direction Policy (hereafter the Sector Direction Policy) (NDRC et al. 2006), which was promulgated earlier in the same year and grouped industries into three categories into which Chinese OFDI is forbidden, permitted, and encouraged. The nuanced difference is, however, that the 2006 Opinions mentioned structural adjustment, which is an extension of domestic economic development via OFDI. Another document that elaborates on the overall direction of the country's OFDI support is the Priority OFDI Projects for Credit Support (hereafter EXIM priorities) by the NDRC and The Export-Import Bank of China (EXIM) (2003, 2004). It sets out guidelines for credit support in order to direct competitive Chinese outward investors seeking natural and strategic resources and foreign markets.

More recently, the country's overall planning policy - the $12^{\text {th }}$ Five-Year Plan on National Economic and Social Development (hereafter the $12^{\text {th }}$ Five-Year Plan) - that guides all economic and social policies between 2011-2015 (Government of China 2011a) has suggested the directions for future OFDI support. The $12^{\text {th }}$ Five-Year Plan encompasses two documents that indicate clear directions for future OFDI support, viz.: the $12^{\text {th }}$ Five-Year Plan on Industrial Reform and Upgrading (hereafter the $12^{\text {th }}$ Industrial Five-Year Plan) (State Council 2011); and the $12^{\text {th }}$ Five-Year Plan on Inward and Outward FDI (hereafter the $12^{\text {th }}$ FDI Five-Year Plan) (NDRC 2012a).

The first document, the $12^{\text {th }}$ Industrial Five-Year Plan, laid out five priorities for industrial sectors that all have potential implications for OFDI:

(1) the outsourcing of production to locations where domestic technologies are established and global demand is high;

(2) the establishment of industrial parks overseas in regions where conditions are advantageous;

(3) international exploration and cooperation projects in important energy and natural resources such as oil and gas, iron ore, uranium, copper, and alumininum, and the building of long-term, stable, safe, and diversified multi-channel supply systems for natural resources;

(4) the construction of R\&D centers in technology-intensive overseas locations and collaboration with foreign R\&D institutions and innovative enterprises; and

(5) comprehensive engineering projects by capable and capital-rich big corporations; M\&As and greenfield investments; the international registration of intellectual property rights; the establishment of global marketing and sales networks and regional sales centers; and global resource configuration and value-chain integration (State Council 2011).

Similarly, to a large extent (and consistent with earlier documents) the $12^{\text {th }}$ FDI Five-Year Plan lays out the future development of the OFDI policy framework. It emphasizes the government's role in promoting OFDI in three priority areas: 
- supporting the active participation of Chinese firms in natural resource projects overseas in order to secure the sustainable, stable, economic, and safe supply of energy and natural resources;

- accelerating the implementation of technological upgrading; and

- effectively implementing the expansion into foreign markets (NDRC 2012a).

The document explicitly states the government's objective of enhancing the competitiveness and independence of Chinese outward investors, where 'competitiveness' encompasses the development of capabilities in R\&D, marketing, logistics, brand names, corporate social responsibility, as well as governance and managerial know-how (NDRC 2012a).

The $12^{\text {th }}$ FDI Five-Year Plan also encourages capable private enterprises, particularly small and medium-sized enterprises (SMEs), to engage in OFDI. The document suggests that the government's efforts to promote private OFDI are the result of an interplay between the two forces mentioned earlier. First, there is the government's emphasis on creating internationally competitive Chinese MNEs in general regardless of their ownership structure. Second, there is the growing voice of (and pressure by) rising investors in the private sector who are calling for improvements to the regulatory regime for OFDI (NDRC 2012a).

The above documents together provide a comprehensive view of the government's objectives regarding China's OFDI, down to specific industries and activities, and they allow for anticipating the central government's likely position on particular projects. For instance, building an R\&D center (see EXIM Priorities and the $12^{\text {th }}$ FDI Five-Year Plan) as a joint venture with a local partner (see $12^{\text {th }}$ Industrial FiveYear Plan) in the pharmaceutical industry (see Sector Direction Policy) would fall into the category of projects perceived by the government as highly desirable. For this reason, it may receive faster administrative processing on the regulatory side. On the promotion side, it might qualify for government support on fiscal, financial, insurance, informational, and other matters.

The next section discusses how the priorities identified above in turn inform the various laws and regulations that are meant to help Chinese firms in their OFDI.

\subsection{The Current Framework is Enabling - but Still Cumbersome}

The principal instruments that define the current OFDI framework governing nonfinancial investments ${ }^{2}$ are:

\footnotetext{
2 'Non-financial' refers to all Chinese investors that do not belong to the banking, securities and insurance sectors. 'Financial' refers to Chinese investors in the banking, securities and insurance sectors.
} 
- the Administrative Measures for Overseas Investment enacted by the Ministry of Commerce of China on 1 May 2009 (hereafter the MOFCOM 2009 Measures) (MOFCOM 2009);

- the NDRC's Interim Administrative Measures for Approving Investment Projects Overseas (hereafter the NDRC Interim Measures), enacted on 9 October 2004 (NDRC 2004); together with

- an array of measures supporting OFDI, notably the 2006 Opinions (State Council 2006) and the provisions contained in the EXIM Priorities, the Sector Direction Policy, the $12^{\text {th }}$ Industrial Five-Year Plan, and the $12^{\text {th }}$ FDI Five-Year Plan.

These instruments deal with two core areas: (1) instituting easier procedures for undertaking OFDI, thereby granting firms greater independence in their decision making; and (2) strengthening and clarifying the MOFCOM's policies and services that relate to OFDI.

The MOFCOM 2009 Measures also did a number of other things. First, they decentralized the authority to approve proposed foreign investments to local departments of commerce, except for a few strategically sensitive matters. Second, they simplified the MOFCOM's approval procedures - there is now only one application form and no more than three business days for approval. Third, they allowed investors themselves to assess the feasibility of their proposed OFDI projects. Fourth, they provided that the MOFCOM would continue its role of negotiating bilateral and multilateral investment agreements, such as bilateral investment treaties (BITs). Lastly, they issued regulations regarding the way in which Chinese investors operate in their host countries.

Similar to the MOFCOM, the NDRC is also in the process of simplifying its approval procedures. On 16 August 2012 the NDRC released the Exposure Draft (for Consultancy and Comments) of Approval Measures for Investment Projects Overseas (hereafter NDRC Exposure Draft) (NDRC 2012b). This document aims further to decentralize the approval process to sub-national offices. In other words, the current institutional framework for China's OFDI is much more decentralized than in the past; moreover, the government actively encourages OFDI through a number of instruments.

Going forward, Beijing aims further to liberalize OFDI regulations ('Outward FDI chapter' 2013) while embedding its approach to OFDI within a broader economic development strategy in both the regulatory and promotion sides. On the regulatory side, the most important governmental actor is the NDRC. As discussed earlier, the NDRC explicitly screens OFDI projects against China's national economic development priorities (NDRC 2011). On the promotion side, there are a few major policy documents where the approach to OFDI can be seen to be embedded within a broader development strategy - in addition to the EXIM Priorities and the Sector Direction Policy discussed earlier, the other major documents here are the $12^{\text {th }}$ Industrial Five-Year Plan and the $12^{\text {th }}$ FDI Five-Year Plan.

All non-financial companies, whether state-owned or private, need to receive approval from the NDRC and the MOFCOM (or their provincial-level offices) before 
they can undertake an overseas direct investment project. Central state-owned enterprises (SOEs) also need to be approved by the State-Owned Assets Supervision and Administration Commission (SASAC). ${ }^{3}$ A roadmap of China's OFDI approval process is laid out in Table 1.

${ }^{3}$ There were a total of 115 SASAC-listed central SOEs as of 12 May 2013. The full list is available at http://www.sasac.gov.cn/n1180/n1226/n2425/index.html. 
Table 1. A Roadmap of China's OFDI Approval Processes, 2013.

\begin{tabular}{|c|c|c|c|c|c|c|c|c|c|}
\hline \multirow[t]{3}{*}{$\begin{array}{l}\text { Ownership } \\
\text { Identity }\end{array}$} & \multirow[t]{3}{*}{ Industry } & \multirow{3}{*}{$\begin{array}{c}\text { Proposed } \\
\text { Investment } \\
\text { by Chinese } \\
\text { Investor(s) } \\
\text { (Millions of } \\
\text { Dollars) }\end{array}$} & \multicolumn{7}{|c|}{$\begin{array}{l}\text { Approval Agencies and Processes } \\
\text { The number of days for approval is provided if specified in the regulatory documents; } \\
\text { "Approval" signifies that an approval is required, but the number of days for the approval processes is not specified; } \\
\text { "Informed" signifies that no approval is needed but a report is required. }\end{array}$} \\
\hline & & & \multicolumn{3}{|c|}{$\begin{array}{c}\text { MOFCOM } \\
\end{array}$} & \multicolumn{2}{|c|}{ NDRC } & \multirow[t]{2}{*}{ SASAC } & \multirow{2}{*}{$\begin{array}{l}\text { Industry Regulator } \\
\text { (CBRC/CSRC/CIRC) }\end{array}$} \\
\hline & & & Provincial & Central & $\begin{array}{c}\text { Embassy or } \\
\text { Consulate Office } \\
\text { (Consultation } \\
\text { Only) } \\
\end{array}$ & Provincial & Central & & \\
\hline \multirow{11}{*}{$\begin{array}{l}\text { Central } \\
\text { SOEs }\end{array}$} & \multirow{5}{*}{$\begin{array}{l}\text { Natural Resources } \\
\text { (Transport and } \\
\text { Infrastructure } \\
\text { NDRC only) }\end{array}$} & $\geq 300$ & & \multirow{8}{*}{$\leq 20$ days } & \multirow{5}{*}{$\leq 10$ days } & & $\leq 30$ days & \multirow{9}{*}{$\leq 20$ days } & \\
\hline & & $100 \sim 300$ & & & & & & & \\
\hline & & $30 \sim 100$ & & & & & & & \\
\hline & & $10 \sim 30$ & & & & & 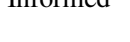 & & \\
\hline & & $<10$ & & & & & & & \\
\hline & \multirow{4}{*}{$\begin{array}{l}\text { Others, Excluding } \\
\text { Financial Services }\end{array}$} & $\geq 100$ & & & $\leq 10$ days & & $\leq 30$ days & & \\
\hline & & $30 \sim 100$ & & & & & & & \\
\hline & & $10 \sim 30$ & & & & & Informed & & \\
\hline & & $<10$ & & $\leq 3$ days & & & & & \\
\hline & \multirow{2}{*}{ Financial Services } & $\geq 100$ & & & & & $\leq 30$ days & & Annroval \\
\hline & & $<100$ & & & & & Informed & & Appioval \\
\hline \multirow{12}{*}{$\begin{array}{l}\text { Sub- } \\
\text { National } \\
\text { SOEs and } \\
\text { Non-SOEs }\end{array}$} & \multirow{5}{*}{$\begin{array}{l}\text { Natural Resources } \\
\text { (Transport and } \\
\text { Infrastructure } \\
\text { NDRC only) }\end{array}$} & $\geq 300$ & \multirow{2}{*}{$\leq 10$ days } & \multirow{2}{*}{$\leq 20$ days } & \multirow{2}{*}{$\leq 10$ days } & & $\leq 30$ days & & \\
\hline & & $100 \sim 300$ & & & & \multirow{4}{*}{ Approval } & Informed & & \\
\hline & & $30 \sim 100$ & \multirow{3}{*}{$\leq 20$ days } & & & & 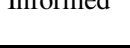 & & \\
\hline & & $10 \sim 30$ & & & & & & & \\
\hline & & $<10$ & & & & & & & \\
\hline & \multirow{4}{*}{$\begin{array}{l}\text { Others, Excluding } \\
\text { Financial Services }\end{array}$} & $\geq 100$ & $\leq 10$ days & $\leq 20$ days & $\leq 10$ days & & $\leq 30$ days & & \\
\hline & & $30 \sim 100$ & \multirow{2}{*}{$\leq 20$ days } & & & \multirow{3}{*}{ Approval } & \multirow{2}{*}{ Informed } & & \\
\hline & & $10 \sim 30$ & & & & & & & \\
\hline & & $<10$ & $\leq 3$ days & & & & & & \\
\hline & \multirow{3}{*}{ Financial Services } & $\geq 100$ & $\leq 10$ days & $\leq 20$ days & $\leq 10$ days & & $\leq 30$ days & & \multirow{3}{*}{ Approval } \\
\hline & & $10 \sim 100$ & & & & \multirow{2}{*}{ Approval } & Informed & & \\
\hline & & $<10$ & & & & & & & \\
\hline
\end{tabular}

Source: The authors, based on MOFCOM (2009), NDRC (2004, 2009, 2011) and Sun and Jiang (2011). 


\section{Investment Regulation ${ }^{4}$}

\section{Approval for Non-Financial Companies}

Any Chinese enterprise in non-financial industries, including legal persons in the public sector, is allowed to invest abroad after approval by both the MOFCOM and the NDRC or their provincial equivalents (MOFCOM 2009; NDRC 2004, 2012b). Through the NDRC, Chinese investments exceeding US\$300 million in natural resources or US\$100 million in other sectors need further approval by the State Council (NDRC 2012b). However, proposed OFDI activities that meet certain criteria for sensitivity are expressly forbidden by the MOFCOM. An investment is prohibited if it would:

- endanger the sovereignty, national security and social public interests of China, or would violate Chinese laws and regulations;

- jeopardize bilateral diplomatic relationships;

- violate bilateral agreements; or

- involve technologies and products that are embargoed for export (MOFCOM 2009).

Beyond these overarching provisions, the MOFCOM and the NDRC have their own approval processes, summarized in Table 1 above and discussed separately below.

\section{MOFCOM Approval Processes}

The MOFCOM 2009 Measures require an investor to obtain a Certificate of Enterprise/Organization Investment Abroad (hereafter the Certificate) ${ }^{5}$ from the MOFCOM after finalizing an OFDI proposal. After obtaining the Certificate, the investor can proceed to buy foreign exchange and obtain customs clearance and other services (such as commercial consulate services). The Certificate becomes invalid if the OFDI activities set out in the proposal do not actually begin within two years after the approval (MOFCOM 2009).

Not all proposed OFDI projects must be submitted to the central office of the MOFCOM for approval. The following investments, however, do need to be approved by the central office in order to obtain the requisite Certificate to proceed (Table 1): any projects conducted by central SOEs, regardless of the investment size; any project by other firms in natural resources; and any project where the committed investment by a Chinese investor is over US\$100 million.

\footnotetext{
${ }^{4}$ The laws and regulations concerning China's OFDI are available from various websites and are updated frequently. For a collection of a number of them, see Wolff (2011) and BernasconiOsterwalder, Johnson, and Zhang (2012).

${ }^{5}$ A sample of the Certificate can be found at http://tfs.mofcom.gov.cn/accessory/200903/1237250375949.doc.
} 
In addition, if a project meets any of the following conditions (regardless of its size), it needs to be approved by the MOFCOM's central office, which has to consult Chinese embassies or consulates in the host countries concerned:

- the investment would be undertaken in a country that has not established diplomatic relations with China;

- the investment would be undertaken in a country that is on a blacklist established by the MOFCOM and the Ministry of Foreign Affairs;

- the proposed investment would affect the interests of a third country (i.e., beyond China and the host country); or

- $\quad$ an investor plans to set up a special purpose vehicle ${ }^{6}$ (MOFCOM 2009).

Lastly, central SOEs that are administered by the SASAC also need to directly apply for the Certificate from the MOFCOM regardless of the size of the proposed investment or whether any of the above four conditions are met.

The approval by the central office of the MOFCOM normally takes no longer than 20 business days. However, non-natural resource projects ${ }^{7}$ in which the committed investment by a Chinese central SOE is under US\$10 million should take no longer than three business days for an approval from the central office (MOFCOM 2009).

Applications for a Certificate for all other projects and enterprises not mentioned above are through local departments of commerce, a process that is supposed to take no longer than 10 business days. Specifically, all other firms (including both sub-national SOEs and non-SOEs) need to obtain a the Certificate from the local Foreign Economic Relations and Trade (FERT) offices. There, the approval process is supposed to take not more than 20 business days (including five business days for confirmation that an application has been received) if any of the following conditions are met:

- the proposed investment by the Chinese investor(s) would be between US\$10 million and US\$100 million; or

- the proposed investment would be in the oil and mining sectors; or

- the proposed investment requires additional domestic financing (MOFCOM 2009).

All other applications - i.e., OFDI projects by sub-national SOEs and non-SOEs where the committed investment by the Chinese investor(s) is below US\$10 million - are administered by the local FERT offices, and the approval process is stated to take only up to three business days (MOFCOM 2009).

\footnotetext{
${ }^{6}$ A special purpose vehicle is a legal entity created by a sponsor or originator firm by transferring assets to the vehicle, to carry out some specific and often temporary purposes or circumscribed activities, or a series of such transactions.

${ }^{7}$ For instance, building a manufacturing facility.
} 
NDRC Approval Processes

The NDRC's role in the current OFDI institutional framework is constituted by three documents. First, the NDRC Interim Measures enacted in October 2004 (NDRC 2004). Second, its supplementary document released in June 2009, No. [2009]1479 Notice on Improving the Administrative Measures of Overseas Investment Projects (hereafter NDRC [2009]1479) (NDRC 2009). Third, the NDRC No. 235 Notice on Decentralizing the Approval Process of Overseas Investment Projects (hereafter NDRC [2011] 235), released in February 2011 (NDRC 2011).

According to these documents, all investors also need to apply for approval by the NDRC or local Development and Reform Commissions (DRCs). OFDI projects in the following categories must also be approved directly by the NDRC:

- the proposed investment is in natural resources and the investment committed by the Chinese investor(s) would be over US\$300 million;

- the proposed investment project is not in natural resources, and the investment committed by the Chinese investor(s) would be over US\$100 million;

- special projects, including investments in: a country without diplomatic relations with China; countries under United Nations sanctions; war zones, as well as investment related to infrastructure, telecommunications, cross-border water utilization, large-scale land exploitation, electricity networks, and news media (NDRC 2004, 2009, 2011).

The approval process is stated to take not longer than 30 business days: 20 business days in principle, plus a maximum of 10 business days if an extension is needed (NDRC 2004).

All other projects undertaken by central SOEs are exempted from approval by the NDRC. The central office of the NDRC does, however, need to be informed before a project is undertaken (NDRC 2004, 2009, 2011).

The approval of other projects - i.e., those undertaken by sub-national SOEs and non-SOEs - is delegated to local DRCs (NDRC 2011). However, the central office of the NDRC needs to be informed before local approval is granted if the committed Chinese investment is between US\$30 million and US\$300 million in natural resource industries, or between US\$10 million and US\$100 million in other industries (NDRC 2011). An approval criterion of the NDRC, but not of the MOFCOM, is that OFDI projects are consistent with China's national strategic priorities. The NDRC also needs to consult the Taiwan Affairs Office of the State Council if the target location is in the Taiwan Province of China (NDRC, MOFCOM, and Taiwan Affairs Office of the State Council 2010).

Local DRC offices can independently approve other projects below the investment thresholds previously specified. However, local DRCs need to inform the 
central office of natural resource investment projects between US\$30 million and US $\$ 300$ million and non-natural resource investment projects between US\$10 million and US\$100 million (NDRC 2011).

On 8 June 2009, the NDRC released NDRC [2009]1479 (NDRC 2009), which amended the existing approval regulations by adding an article regarding OFDI through acquisitions or tenders (both open and private). The article requires Chinese investors to provide the NDRC or their provincial DRC offices with detailed information such as the investor's profile, project background, target profiles, due diligence, acquisition or tender plans and timelines (NDRC 2009). The NDRC or its provincial equivalents are supposed to provide confirmation documents within seven business days (NDRC 2009).

In an effort to simplify and decentralize its approval process, the NDRC released NDRC [2011] 235 on 14 February 2011 (NDRC 2011) and the NDRC Exposure Draft on 16 August 2012 (NDRC 2012b). The major proposed change is that the investment value threshold for approval by the central office of the NDRC is to be raised from US $\$ 100$ million to US\$300 million for infrastructure and transportation projects, which are currently classified as part of non-natural resource projects. Additionally, the NDRC Exposure Draft seeks to amend NDRC [2009]1479 by proposing a threshold of US $\$ 100$ million, below which no report to the NDRC or its provincial equivalents is required (NDRC 2009, 2012b). These changes, if enacted, will expedite the review process.

The MOFCOM 2009 Measures (MOFCOM 2009) do not mention exemptions to the approval process. Similarly, the NDRC Interim Measures (NDRC 2004) as well as NDRC [2009]1479 (NDRC 2009) and [2011] 235 (NDRC 2011) do not mention exemptions except for central SOEs that meet one of two conditions. First, a central SOE will be exempt from approval for OFDI projects in natural resources, transport, and infrastructure in which the committed Chinese investment is below US\$300 million. Second, they will be exempt for OFDI projects in other industries where the committed Chinese investment is below US $\$ 100$ million. For either of these two types of OFDI projects, the investing central SOE can take its own investment decision but is required to inform the central office of the NDRC (NDRC 2011). In other words, any other OFDI proposals of any size and in any area are required to apply for approval by both the MOFCOM and the NDRC or their local equivalents. In fact, any agreements or contracts signed by a Chinese investor without approval by the MOFCOM and the NDRC are not legally binding (NDRC 2004, 2011; MOFCOM 2009).

\section{SAFE Review Processes}

Chinese investors need to present their OFDI approvals received from the NDRC and the MOFCOM before transferring foreign exchange offshore through SAFE for investments overseas (SAFE 2009). SAFE is also responsible for examining the sources of the foreign exchange in an applicant's domestic account (SAFE 2009). The amount of the foreign currency purchase must be consistent with the OFDI approval documents provided by the 
NDRC and the MOFCOM. The purchase of foreign exchange to cover pre-investment fees $^{8}$ should not exceed $15 \%$ of the total OFDI value (SAFE 2009). If an investment is not completed within six months after the remittance of the pre-investment fees, all foreign currencies remaining in the overseas banking account for the OFDI project are required to be transferred back to the domestic banking account in China (SAFE 2009).

\section{A Summary}

It is cumbersome, if not redundant, to have two independent ministerial agencies design and implement OFDI policies and regulations. This duality creates extra investment costs due to overlapping procedures and potential delays due to bureaucracy (e.g., days for applicants to figure out who does what). Given that the NDRC is the central machinery that designs current and new development policies (including those for the MOFCOM), it would be more efficient if the review and approval functions were concentrated in the NDRC for both non-SOEs and SOEs, and if such a review were limited to identifying the projects that should receive special support. Given the MOFCOM's unique resources associated with its global network of commercial consulate offices, the MOFCOM's functions could be more service-oriented. For instance, it could be dedicated to providing information and advice and matchmaking investors to prospective projects. So as not to overlap with the NDRC, the function of the SASAC (as principal shareholder of the central SOEs) could be limited to ensuring that shareholder interests such as dividends and profitability are safeguarded.

But there is also a broader question. Some 14,000 Chinese firms had established nearly 18,000 foreign affiliates abroad as of the end of 2011 (MOFCOM 2012b, 3). As Chinese OFDI continues to rise, more firms are becoming outward investors and more foreign affiliates will be established. In turn, a growing number of these are likely to establish a rising number of their own affiliates abroad. This context means that it may simply become impossible to meaningfully review and approve each OFDI project - the creation of a huge bureaucracy would be required to undertake this task, otherwise the approval system would simply collapse under its own weight (Bath 2011). In fact, even now it appears that a number of firms (especially SMEs) invest abroad without formal approval, i.e., they manage to elude the approval process altogether. This diminishes the ability of the government to direct FDI into the areas that it considers a priority. The implication is that sooner or later, the government will have to move to a simplified approval regime in which only the largest (or most sensitive) projects will require approval, while a simple registration process would suffice for the great majority of OFDI projects.

\section{Approval for Financial Companies}

Chinese financial companies undertaking OFDI need to apply for approval by the NDRC,

${ }^{8}$ E.g., deposits, pre-investment market research costs, pre-investment consulting, and legal service fees. 
the People's Bank of China and their industry regulators. ${ }^{9}$ All the NDRC approval policies and regulations discussed earlier also apply to Chinese outward investors in the financial industries. Between April 1990 and January 2011, The Administrative Measures of Financial Enterprises Overseas was the principal regulation guiding outward investment by Chinese financial companies (PBC 1990). Since the abolition of that regulation in January 2011 (Government of China 2011b), the three financial industry regulators have been drafting their own industry-specific administrative measures on outward investment by Chinese financial companies. On 22 October 2012, the China Insurance Regulatory Commission released its Interim Measures of Investments Overseas by Chinese Insurance Companies (CIRC 2012). As of October 2013, no such principal regulation on outward investment had been released by either the China Banking Regulatory Commission or the China Securities Regulatory Commission. ${ }^{10}$ Given the complexity, flexibility, and vast impact of financial sector investments, greater transparency of the guidelines for the other two regulators is desirable.

Monitoring

The MOFCOM and the SAFE jointly monitor post-investment activities through, among other documents, the Interim Measures for Joint Annual Inspection of Overseas Investment (MOFCOM and SAFE 2009). ${ }^{11}$ The evaluation criteria focus on:

- economic and financial indicators, including corporate profitability, operational performance, asset quality, and solvency;

- growth potential, for example, market share, sales, labor efficiency; and

- the economic contribution to China, for example, tax, foreign exchange creation, natural resources (MOFCOM and SAFE 2009).

All the relevant review activities by the MOFCOM, its sub-national equivalents, and the SAFE after 2009 have had this document as their policy basis. More recently, the MOFCOM has gradually shifted its monitoring from economic and financial indicators to include social, environmental and ethical indicators as well. This is a welcome move, especially in relation to Chinese firms in developing countries where environmental and other regulations (and their implementation) are relatively weak.

\footnotetext{
${ }^{9}$ I.e., the China Banking Regulatory Commission, the China Securities Regulatory Commission and the China Insurance Regulatory Commission.

${ }^{10}$ A detailed list of the policies and regulations of the China Banking Regulatory Commission can be found at http://www.cbrc.gov.cn/chinese/zhengcefg.html. A similar list for the China Securities Regulatory Commission can be found at http://www.csrc.gov.cn/pub/zjhpublic/index.htm?channel=3300/3311 (both sites accessed on 16 January 2013).

${ }^{11}$ For an example of the full list of the performance measures under review, see http://hzs.mofcom.gov.cn/article/zcfb/b/200403/20040300198964.html.
} 
An example of this policy expansion is the joint announcement by the MOFCOM and the Ministry of Forestry in March 2009 of the Guidebook of Sustainable Operations and Exploration of Overseas Forests by Chinese Enterprises (MOFCOM and Ministry of Forestry 2009). ${ }^{12}$ Then, in July 2010, the MOFCOM, the Ministry of Environmental Protection's Chinese Academy for Environmental Planning, and the Global Environmental Institute (2010) jointly published a guide entitled Environmental Protection Policies on Chinese Investment Overseas to regulate the social and environmental behavior of Chinese investors abroad.

This policy pattern continued in August 2010, when the MOFCOM together with a number of other ministries and government agencies ${ }^{13}$ issued the Work Safety Regulations on Chinese-Invested Enterprises and Organizations Overseas (MOFCOM 2011). These new regulations seek to protect the $1,220,000$ employees working in Chinese foreign affiliates, including 888,000 foreign citizens as of the end of 2011 (MOFCOM 2012a, 5). In May 2012, the MOFCOM jointly released the Opinions on Corporate Culture Construction in Chinese Enterprises Overseas together with several other ministries and government agencies. ${ }^{14}$ The object of that document is to promote a corporate culture of social responsibility (for instance), and integration with local communities and high quality control (MOFCOM 2012b).

Relatedly, the Banking Regulatory Commission's Green Credit Guidelines require that Chinese banks financing overseas projects monitor and supervise the environmental standards observed in the projects they finance (CBRC 2012). Later on, in February 2013 the MOFCOM and the Ministry of Environmental Protection (2013) issued the Guidelines for Environmental Protection in Foreign Investment and Cooperation. More recently, in March 2013 the MOFCOM released the Regulations of Behavior in Competition Abroad in the Area of International Investment and Cooperation. This proposes to build a credit system that records unethical behavior by Chinese enterprises abroad (e.g., bribery, unfair pricing, collusion in bidding, slander, and false company reports) (MOFCOM 2013a).

However, as pointed out by some non-governmental organizations (e.g., the World Resources Institute), it remains to be seen how Chinese investors overseas interpret these policies and to what extent these guidelines are actually monitored, enforced, and sanctioned (Leung, Zhao, Ballesteros, and $\mathrm{Hu} 2013$ ). One way in which the government of China could further extend desirable coporate behavior is by ranking the extent to which Chinese MNEs observe standards of corporate social responsibility in

${ }^{12}$ Chinese forestry companies also need to comply with the rules of the State Forestry Administration (2010).

${ }^{13}$ The Ministry of Foreign Affairs, the NDRC, the Ministry of Public Safety, the State Administration of Work Safety, and the All-China Federation of Industry and Commerce.

${ }^{14}$ Namely, the International Communications Office of the Communist Party of China's Central Committee, the Ministry of Foreign Affairs, the NDRC, the SASAC, the National Bureau of Corruption Prevention, and the All-China Federation of Industry and Commerce. 
host countries. The behavior of Chinese firms could perhaps be benchmarked against international norms, and weak performance in this respect could even be sanctioned. This will become even more important as host countries pay greater attention to attracting sustainable FDI, ${ }^{15}$ and in the event that international investment agreements (and their dispute settlement procedures) become more sensitive to this issue (Sauvant and Ortino 2013). At the same time, helping to ensure that MNEs operate correctly abroad is not only a challenge for China but for all home countries.

Central SOEs and their subsidiaries are also subject to special monitoring by the SASAC, in line with the Interim Supervision Measures of SOEs' Investment Overseas enacted on 1 May 2012 (SASAC 2012). Through this new policy, the SASAC seeks to ensure that the operations of SOEs abroad support China's economic and social objectives and that they are consistent with the objective of transforming China's industrial structure. SOEs are required to report to the SASAC about their internal rules governing OFDI. Such internal rules include principles applied to govern their corporate affairs, the management team and its responsibilities, the internal process of investment decision-making and governance, risk management overseas, investment performance assessment and auditing, and key personnel, as well as internal rules for supervising OFDI activities. A difference of this policy compared to previous ones is that SOEs are not allowed to invest in industries beyond their core businesses (SASAC 2012).

Given that this new policy strengthens the SASAC's capacity for scrutiny and its regulation procedures, it remains to be seen whether this may slow down future OFDI by Chinese SOEs. The management of state assets is a complicated issue in any country, as it usually combines both economic concerns (e.g., profitability) with socio-political ones (e.g., maintaining employment, supporting domestic development). In any event, the management practices of SOEs ought to be transparent, so that host countries can understand the benefits that OFDI by SOEs can bring to their economies.

\section{Investment Promotion}

The Chinese government supports OFDI through financial and fiscal measures, risk management, the provision of information, international support through foreign aid, and the conclusion of international investment agreements. As mentioned before, the EXIM Priorities, the Sector Direction Policy, and the $12^{\text {th }}$ Industrial and FDI Five-Year Plans are all important instruments that guide governmental support for OFDI in selective foreign industries and projects.

Financial and Fiscal Support

\footnotetext{
${ }^{15}$ I.e., investment that makes a maximum contribution to the economic, social and environmental development of the host country, and that takes place within a framework of fair governance systems (e.g., when negotiating large-scale complex contracts with host countries).
} 
The EXIM and other state-owned commercial banks offer low lending rates, a fast approval process, and flexible terms for OFDI projects. For instance, in line with the EXIM Priorities, the NDRC and the EXIM established a Special Fund of Lending for Investment Overseas to provide credit support for OFDI into priority projects (NDRC and EXIM 2003, 2004). Later, in an agreement between the China Development Bank and the EXIM in February 2006, special financial services (including discounted leanding rates) were extended to:

- exploration projects for mineral and forestry resources;

- other projects of benefit to multilateral governmental cooperation; and

- central SOEs and large-scale business groups that possess sufficient capital, technology, management know-how, and brands (CDB and EXIM 2006).

If lending is in Renminbi (RMB), the discounted lending rates are capped at the benchmark rate set by the People's Bank of China, or at $3 \%$ if in a foreign currency (Luo et al. 2010). The SAFE has also gradually lifted its limitations on buying foreign exchange for OFDI; following the Foreign Exchange Administrative Regulations for Domestic Institutions Investing Abroad, no further approval for foreign exchange purchases is required by the SAFE once a project and its committed amount of foreign exchange are approved by the MOFCOM and the NDRC (SAFE 2009).

In addition, through a special fund jointly established and managed by the Ministry of Finance and the MOFCOM, the Chinese government provides direct subsidies to qualifying OFDI projects. Projects that qualify are activities such as: building foreign R\&D centers and machinery and equipment manufacturing facilities; investments in Chinese-built economic and trade zones overseas; and investment in natural resources $^{16}$ (Ministry of Finance and MOFCOM 2012).

The State Administration of Taxation also provides a series of tax deductions and exemptions to support China's 'go out' strategy (SAT 2007). They include, for instance: regular deductions and exemptions of both corporate and individual incomes to avoid double taxation (SAT 2010); tax reductions for revenues from oil and gas extraction overseas by Chinese enterprises (SAT 2011); and a special corporate income tax (reduced from a normal tax rate of $25 \%$ to $15 \%$ ) for high-technology enterprises certified by the Ministry of Science and Technology (SAT 2011).

Lastly, in January 2011, the Peoples' Bank of China introduced and immediately started to implement a new foreign exchange policy, viz. OFDI settling accounts in RMB (PBC 2011). This allows Chinese firms to mitigate foreign exchange risks by directly using RMB to invest abroad if certain conditions are met. The conditions are that the

\footnotetext{
${ }^{16}$ For instance, up to $20 \%$ of the carrying costs can be covered through subsidies for a Chinese natural resource-seeking investor to transport natural resources back to China (Luo et al. 2010, 76).
} 
applicant firm should be a registered non-financial enterprise in a province in which cross-border trade settlement accounts in RMB are allowed, and the host country must allow for settlement of FDI accounts in RMB (PBC 2011).

\section{Risk Management}

In addition to the protection afforded by the 125 BITs between China and other nations as of 1 June 2013 (UNCTAD 2013b) and other international investment agreements, Chinese investment overseas may also be able to obtain protection from SINOSURE through its various insurance products and services. Enterprises and financial institutions that are registered in mainland China and operate there as the principal location of their business, as well as financial institutions that provide finance for OFDI by the enterprises mentioned above, can apply for investment insurance from SINOSURE. Projects that qualify for insurance include new OFDI projects, as well as existing, expanding and changing projects. SINOSURE insures against the loss of capital and earnings abroad directly caused by expropriation, restrictions on the transfer and conversion of funds, damage from war, the inability to operate due to war, and breach of contractual undertakings.

Provision of Information

Through its global commercial consulate offices, the MOFCOM provides information on investment opportunities abroad. Equally important, the Catalogue of Countries and Industries for Guiding Investment Overseas (hereafter the Catalogue) provides information about the FDI attraction priorities of 127 foreign destinations, ${ }^{17}$ with a list of those industries that are a priority for each host country (NDRC 2007). Many of these host country priorities are also shared by China. The Catalogue consists of three parts, released in July 2004, October 2005, and January 2007 (NDRC 2007). Continuing and expanding this effort, the MOFCOM established the Global Investment and Cooperation Information Service System in 2008, which integrates services such as the collection of information and statistics and decision-making support (MOFCOM 2013b, 24). ${ }^{18}$

In addition, the MOFCOM works with the NDRC and the Ministry of Foreign Affairs to publish the annual OFDI Guidebook of Countries for International Investment and Cooperation (hereafter the Guidebook). The Guidebook lists current investment opportunities by country, industry, and project, seeking to facilitate OFDI flows. The latest version (published on 21 December 2012) covers 165 countries (MOFCOM 2012d). Indeed, unless this effort is continuously updated, its value will decrease. It is a

\footnotetext{
${ }^{17}$ The Catalogue has three parts, which can be downloaded through the following links: www.china.com.cn/chinese/PI-c/626171.htm (Part 1); www.sndrc.gov.cn/view.jsp?ID=9674 (Part 2); and http://www.sdpc.gov.cn/zcfb/zcfbtz/2007tongzhi/W020070227622797287359.doc (Part 3).

${ }^{18}$ The system is available online at http://femhzs.mofcom.gov.cn/fecpmvc/pages/fem/LoginedHome.html.
} 
useful tool that also shows how the Chinese government is keen to encourage OFDI in areas that are of priority to host countries, with the side benefit that Chinese investors pursuing the investment opportunities might be able to benefit from the various incentives that host countries may offer.

For major natural resource-seeking OFDI projects, the government also serves as a leader of Chinese investment consortia (that consist of a number of companies) and disseminates information about various investment and cooperation opportunities to the members of these consortia as well as others (Li, Newenham-Kahindi, Shapiro, and Chen 2013). In addition, government agencies like the China Council for the Promotion of International Trade conduct annual OFDI surveys of country investment environments and build a databank of OFDI intentions by Chinese firms. ${ }^{19}$

\section{International Support Through Development Assistance Programs}

China has a relatively long history of overseas development assistance. One such assistance program involves the construction of foreign economic and trade cooperation zones (FETCZs). Guided by the Chinese government, FETCZs are built to have a developed infrastructure, to include a full set of value chains, and to impact other industries (Zhang 2011). FETCZs are mostly designated to focus on export processing and scientific and technological projects (Zhang 2011). Since 2006, the MOFCOM has approved a total of 19 FETCZs; by October 2012, 250 Chinese firms had set up affiliates in those zones with US\$3.6 billion committed in OFDI and the creation of 17,000 local jobs (MOFCOM 2012c). Broadly speaking, there are three types of these zones: manufacturing and processing zones in countries like Cambodia, Pakistan, the Republic of Korea, Thailand, Venezuela, and Vietnam; resource exploration zones in places such as Russia and Zambia; and regional trade zones and assembly zones in countries like Egypt, Mauritius, and Russia.

More broadly, as part of its assistance program China also supports OFDI projects, especially in Africa. For example, the Chinese government led a group of mining investors to negotiate with local investment bureaus for better investment conditions and opportunities in Tanzania ( $\mathrm{Li}$ et al. 2013). The major policy oriented financial institutions are the EXIM and (before it was restructured and corporatized) the China Development Bank (Government of China 2008). They provide concessional loans subsidized by China's foreign aid budget. Additionally, the China Development Bank has established international cooperative funds with many countries to support Chinese operations overseas through concessional loans (Chen 2012). In 2008, the China Development Bank was restructured and corporatized as a commercial bank under the China Banking Regulatory Commission and thus is no longer a policy bank (Government of China 2008). Apart from these concessional loans, China's aid program also provides

\footnotetext{
${ }^{19}$ Further information about surveys by the China Council for the Promotion of International Trade is available at http://www.ccpit.org/zhuanti/zouchuqu/Channel_1085.htm?ChannelID=1085.
} 
aid and no-interest loans for construction and civil development projects (Information Office of the State Council 2011).

International Investment Agreements

Traditionally, developed countries have concluded international investment agreements and free trade agreements (FTAs) with substantial investment provisions to protect the investments of their firms abroad and facilitate their operations. Initially, like other developing countries, China concluded such agreements primarily to help attract FDI. With the rise of the country's OFDI, however, China also began to look at these agreements from the perspective of a home country seeking to protect its investors through provisions on national treatment, most-favored-nation treatment, fair and equitable treatment, protection from expropriation, and access to international dispute settlement.

As of 1 June $2013,{ }^{20}$ China had more BITs than any other country except Germany (125 versus 134) (UNCTAD 2013c). China is negotiating a BIT with the United States ('China-US Strategic' 2012; Sauvant and Chen 2012) and is considering whether to negotiate an international investment agreement with the EU (EU 2010). In addition to individual BITs, China is a signatory to investment agreements with groups of countries. The most recent (2012) example of this is an agreement with Japan and the Republic of Korea, ${ }^{21}$ covering economies with an aggregate economic weight that is similar to that of the members of the North American Free Trade Agreement. China is furthermore a signatory to 10 FTAs that contain provisions on investment promotion and protection. In addition, China is negotiating FTAs - that if concluded are likely to contain investment provisions - with Australia, the Gulf Cooperation Council, ${ }^{22}$ Iceland, Norway, the Southern African Customs Union (SACU), and Switzerland.

\section{Evaluation of the Current Framework by Chinese Outward Investors}

The previous discussion has provided a comprehensive review of the objectives of the OFDI policy regime and the manner in which they have been implemented. To the best of our knowledge, there are few independent studies evaluating how successful this policy approach has been. However, the China Council for the Promotion of International Trade (CCPIT) - one of the oldest and largest Chinese associations to promote international trade and outward investment, with more than 68,000 Chinese member firms - has undertaken annual surveys of firms that also included questions dealing with OFDI

\footnotetext{
${ }^{20}$ The date of the latest update of UNCTAD's BIT list.

${ }^{21}$ The Agreement Among the Government of Japan, the Government of the Republic of Korea and the Government of the People's Republic of China for the Promotion, Facilitation and Protection of Investment can be accessed at http://www.mofa.go.jp/announce/announce/2012/5/pdfs/0513_01_01.pdf.

${ }^{22}$ Consisting of Bahrain, Kuwait, Oman, Qatar, Saudi Arabia, and the United Arab Emirates.
} 
(CCPIT 2012). According to the 2011 survey $^{23}$ of 333 Chinese firms, the percentage of Chinese outward investing firms (regardless of whether state or privately owned) that identify China's 'go out' policy as an important or very important factor in their OFDI decision-making process did not rise over the 2005 level - in both 2005 and 2011, this was stable at $55 \%$ of all responses (CCPIT 2012). ${ }^{24}$

More interestingly, this percentage (55\%) was higher than all other factors influencing OFDI decision-making - including the host country's legal system, and natural resources and labor costs - except for the host country's market size and potential (56\%). Two more findings are of particular interest as they imply that China's OFDI institutional framework is more important for SOEs than for private enterprises. First, in the 2011 survey, the 'go out' policy was tied with the host country's market size and potential as the most important factor influencing the OFDI of SOEs (61\%). Second, the importance of the 'go out' policy in OFDI decision-making was greater for SOEs (61\%) than for private enterprises (53\%) (CCPIT 2012).

The 2011 survey reveals that about $74 \%$ of respondents (including both SOEs and private enterprises) indicated that they had benefitted from the government's overall OFDI policies. Within the overall policy framework, however, some polices and measures are more beneficial than others and their benefits for SOEs and private firms tend to be different. Respondents indicated that the four most beneficial policies concerned foreign exchange, the simplification of approvals like customs clearance, the provision of information on investment opportunities abroad, and risk management through protecting the safety of expatriates. More than two thirds of respondents reported that they benefited from these four policies (CCPIT 2012).

However, the OFDI framework seems to be more beneficial for SOEs than private enterprises. Eighty three per cent of respondent SOEs in the same survey reported that the current OFDI policies are beneficial for their OFDI activities overall, compared to only $70 \%$ of private enterprises. The four most helpful OFDI policies for SOEs were: financial and fiscal support through subsidies and special funds; foreign exchange policy support, such as simplifying the procedures for purchasing foreign exchange; the provision of information on investment opportunities; and the provision of information through the Guidebook. For private enterprises, however, the four most helpful policies were: foreign exchange policy support; insurance for expatriates; the simplification of approvals such as customs clearance; and the provision of information on investment opportunities. The common areas pinpointed by both SOEs and private enterprises were foreign exchange policy support and the provision of information on investment opportunities. When comparing SOEs and private enterprises, more SOEs seemed to be subsidized to undertake OFDI and to benefit from the government's provision of information, but they

${ }^{23}$ The report was published in 2012 .

${ }^{24}$ The 2005 survey did not have the category of 'important', but only 'very important' on a seven point scale. For the purpose of this paper, 'important' was defined as the rankings that indicated a ' 5 ' and ' 6 ' out of 7 on the scale. 
were also subject to greater restrictions and scrutiny regarding approvals and foreign exchange. Private enterprises were relatively more concerned about the protection of their expatriates.

The most recent policy announced and immediately implemented by the NDRC may alleviate the de facto policy discrimination against private investors. Noticing the rise of OFDI by Chinese private enterprises, in August 2012 the NDRC ${ }^{25}$ jointly released the Implementation Opinions on Encouraging and Guiding Private Enterprises to Engage in Investment Overseas (NDRC 2012c). This document laid out five major measures, viz. to:

(1) strengthen the macro-level guidance and coordination for OFDI by private enterprises;

(2) enhance financial and fiscal support for private enterprises, such as loans from special international cooperative funds and tax deductions;

(3) simplify the approval and management measures for OFDI by private firms;

(4) improve public services for OFDI by private enterprises, such as incubating global brands; and

(5) protect expatriates and foreign assets for private enterprises.

Another example of the growing attention devoted by the government to private enterprise is the creation of the SME International Market Development Fund (hereafter SME IMDF) by the Ministry of Finance in 2001 (SME IMDF 2012). Moreover, the Guideline for Accelerating the Promotion of International Cooperation and New Competitive Advantages (hereafter the Guideline) (NDRC et al. 2012) contains a new comprehensive policy directive for promoting all types of international activities by Chinese firms. The directive explicitly states that one of the Guideline's major goals is to promote the overseas clustering of Chinese SMEs (NDRC et al. 2012). However, in the case of SMEs that hold export licenses and have less than US\$45 million in export revenues in the year gone by, the SME IMDF could cover up to $70 \%$ of the cost of selective qualified activities overseas under certain conditions (SME IMDF 2012). Such conditions include that the applicants are based in central or western provinces or in former north-eastern industrial centers, or the target country is an emerging market (SME IMDF 2012). The coverage is up to 50\% for other applications (SME IMDF 2012).

In addition, the SME IMDF (2012) explicitly specifies that priority will be given to applicants targeting emerging markets. One of the qualifications for receiving SME IMDF support is OFDI-related: the international acquisition of foreign strategic assets (e.g., technology, brands) (SME IMDF 2012). Correspondingly, the SAFE released its Circular on Encouraging and Prompting Healthy Development of Private Investment (2012). There are three consequences of that document. First, there is no more registration for foreign exchange repatriation because of a capital reduction or divestment

${ }^{25}$ Together with the MOFCOM, the Ministry of Foreign Affairs, the Peoples' Bank of China, and eight other ministries. 
from overseas. Second, the review process for international lending has now been simplified. Third, Chinese individuals are allowed to be co-guarantors with Chinese enterprises for the international financing of Chinese-owned firms overseas (whereas previously, only enterprises could be guarantors).

Going forward, Chinese investors hope to receive more government support led by fiscal incentives. About $70 \%$ of respondents in the 2010 CCPIT survey and almost half of those in 2009 called for more fiscal incentives for their OFDI activities (authors' estimation based on CCPIT's raw survey data). In addition, they wanted to see more by way of financial incentives, the simplification of procedures, international matchmaking opportunities and high quality research in the Guidebooks (authors' estimation based on CCPIT's raw survey data). While the availability of such support may not determine an investment decision, it can make a difference at the margins. And of course, firms always welcome whatever support they can obtain from home and host countries.

\section{Challenges Ahead}

This paper has provided a review of China's regulatory framework that governs the country's OFDI. With significant OFDI beginning only a decade ago, China has rapidly become the most important home country among all emerging markets and the third largest foreign investor in the world in $2012 .^{26}$ This growth may well continue in the near future, even though it will probably proceed at a slower pace. The rapidity with which China has ascended to such an important position has in and of itself focussed considerable attention on the growing significance of China in the world FDI market.

Another facet of China's OFDI that has attracted attention is that unlike in any other important home country, SOEs have so far played a dominant role in the growth of Chinese foreign investment although the role of private enterprises is on the rise. In fact, a few large central SOEs account for the bulk of China's OFDI, ${ }^{27}$ while many small private enterprises and sub-national SOEs account for the rest (much of it in manufacturing and services). The dominant role of SOEs has, in turn, raised all sorts of questions regarding their impact on host countries, an issue that will need careful consideration in the future. ${ }^{28}$

It is clear that China now has a regulatory framework in place that enables OFDI. The overall objectives of this framework are to nurture globally competitive Chinese firms and to advance the country's domestic development. China's regulatory and promotional measures are consistent with these objectives. Improvements are, however,

\footnotetext{
${ }^{26}$ Based on 2012 data, China was only behind the United States (with foreign direct investment flows of US\$329 billion) and Japan (US\$123 billion).

${ }^{27}$ This high concentration of OFDI in terms of the number of MNEs is typical for many home countries.

${ }^{28}$ For a discussion of the range of issues surrounding FDI by state-controlled entities, see Sauvant, Sachs, and Schmit Jongbloed (2012).
} 
needed in many areas. In particular, the complex and long approval process involving two sets of institutions is cumbersome: in the case of financial OFDI, projects need to be reviewed by at least one government agency and non-financial OFDI must be reviewed by two agencies. This process creates extra costs for outward investing Chinese firms, which already need to cope with the liability of foreignness (the extra cost of doing business only borne by foreigners), the challenge of being newcomers in the world FDI market, and the challenge of the liability of the home country (the extra cost of doing business only borne by firms of certain national origins). These kinds of extra costs can be crucial when an investment (e.g., a M\&A) has to be made in a time-sensitive manner. Streamlining the institutional framework is therefore desirable.

As part of this proposed simplification process, a one-stop shop for OFDI could be established to streamline the approval process and bundle together the various support measures that are available for outward investors. Moreover, the threshold at which approval is required for a given OFDI project could - and should - be raised and eventually abolished (at least for the bulk of OFDI projects that are below a certain size). Of course, this would diminish the ability of the government to direct FDI in accordance with its development priorities. An implication would be that the various incentives the government has in place to encourage OFDI in line with its priorities would become more important.

Despite some teething problems, in contrast to the great majority of emerging markets, China has a sophisticated array of instruments in place that facilitate, support, and encourage OFDI. These instruments include the provision of information, investment insurance, financial and fiscal support, linkages to development assistance programs, and international investment agreements. Although these instruments are also common in other countries, a unique characteristic in the Chinese context is that many of them are directed to specific industries and activities in support of the country's development effort. Because of their (historically) larger size and connections with the government, SOEs seem to benefit more from these governmental instruments. For example, large OFDI projects usually require substantial funds, financial leverage, and risk protection through/from domestic financial institutions (most of which are controlled by the central government). It is difficult for smaller private enterprises to obtain such support - an obstacle they share with SMEs elsewhere.

Although China is not unique in supporting its firms in their quest to internationalize through FDI, only a few countries (such as Singapore) have an economic development strategy in place that fully integrates OFDI into it (Sauvant et al. Forthcoming). One cannot therefore understand China's OFDI institutions without understanding China's national development objectives, particularly the promotion of industrial transformation. Through scrutiny by the MOFCOM and the NDRC (or their local equivalents), China's government extends special support to FDI projects that make a particular contribution to the country's national development objectives. Achieving some of these objectives will, however, require further institutional reform in China. For 
instance, to encourage the transfer of technology from foreign affiliates back to parent companies at home will require that China establishes a stronger regime for enforcing intellectual property rights. This is desirable in any event given the growing technological and innovatory prowess of Chinese firms.

The rise of China's OFDI is creating both threats and opportunities. The principal threat is that unwarranted suspicions about this investment and its impact will come to dominate the approach by host countries (and particularly developed countries) to China's OFDI. If that threat eventuates, it will be detrimental to both China's economic development and the economic development of host countries, which would forego the opportunity of benefitting from the tangible and intangible assets associated with FDI from China. It would further be detrimental to the overall integration of China into the world economy. China, the host countries of its OFDI, and the world economy at large, therefore have an incentive to ensure they have policies in place that allow them to minimize any negative effects and maximize the positive effects that spring from the rapid rise of China's OFDI.

\section{References}

2012. "China-U.S. Strategic and Economic Dialogue Will Announce the Restarting of the Negotiations on BITs." Xinhua News Agency, April 28. http://news.xinhuanet.com/world/2012-04/28/c_111860429.htm.

2013. "Outward FDI Chapter: How to 'Go Out' Smoothly?" China Business Update, April 24. http://www.cbusiness.cn/article/cbuzgjm/cbutbch/201304/1241347_1.html.

Bath, V. 2011. “The Quandary for Chinese Regulators: Controlling the Flow of Investment into and out of China. In Foreign Investment and Dispute Resolution Law and Practice in Asia,edited by Vivienne Bath and L. Nottage. London: Routledge.

Bernasconi-Osterwalder, N., Johnson, L., and J. Zhang. 2012. Chinese Outward Investment: an Emerging Policy Framework. Winnipeg, Canada: International Institute for Sustainable Development. http://www.iisd.org/pdf/2012/chinese_outward_investment.pdf.

Buckley, P.J., Clegg, J.L., Cross, A.R., Voss, H., Rhodes, M, and P. Zheng. 2008. "Explaining China's Outward FDI: an Institutional Perspective". In The Rise of Transnational Corporations from Emerging Markets: Threat or Opportunity?, edited by K.P. Sauvant, 107-157. Northampton, MA: Edward Elgar Publishing Limited.

CBRC. 2012. Green Credit Guidelines. Beijing: CBRC. http://www.cbrc.gov.cn/EngdocView.do?docID=3CE646AB629B46B9B533B1D 8D9FF8C4A.

CCPIT. 2012. Survey on Chinese Enterprises' Outbound Investment and Operation. Beijing: CCPIT. http://www.ccpit.org/docs/2012-0803/2012_haiwaitouzi_diaochabaogao.pdf. 
CDB, and EXIM. 2006. CDB and EXIM Enhance their Financial and Insurance Support for Key Investment Projects Overseas Encouraged by the State [CDB 2006 No. 11 Order]. Beijing: CDB and EXIM. http://www.sdpc.gov.cn/wzly/jwtz/jwtzzn/t20060228_61392.htm.

Chen, V.Z. 2012. "Puzzles and Truths about Indian Outward FDI: Toward a More Relevant and Nuanced Research Agenda on Emerging-Market Multinational Enterprises." AIB Insights 12(3): 11-14.

Chen, Y. 2009. "The Formation and Important Impact of Jiang Zemin's 'Going Out' Strategy." CCCPC Party Literature Research Office Website. Accessed October 23, 2013. http://www.wxyjs.org.cn/wxzj_1/dbzb/201305/t20130531_140005.htm.

CIRC. 2012. The Circular for Releasing the 'Implementation Details of the Interim Measures of Investments Overseas by Chinese Insurance Companies'. Beijing: CIRC. http://www.circ.gov.cn/web/site0/tab68/i224574.htm.

Cui, L., and F. Jiang. 2012. "State Ownership Effect on Firms' FDI Ownership Decisions Under Institutional Pressure: a Study of Chinese Outward Investing Firms." Journal of International Business Studies 43: 264-284.

European Union. 2010. Communication from the Commission to the Council, the European Parliament, the European Economic and Social Committee and the Committee of the Regions: Towards a Comprehensive European International Investment Policy. Brussels: EU. http://trade.ec.europa.eu/doclib/docs/2011/may/tradoc_147884.pdf.

Government of China. 2006. Outward Direct Investment Steady. Beijing: Government of China. http://www.gov.cn/english/2006-01/25/content_170714.htm.

Government of China. 2008. China Banking Regulatory Commission Answers the Questions about the Restructuring of China Development Bank. Beijing: Government of China. http://www.gov.cn/gzdt/2008-12/23/content_1185268.htm. Government of China. 2011a. The 12th Five-Year Plan on National Economic and Social Development (2011-2015). Beijing: Government of China. http://www.gov.cn/2011lh/content_1825838.htm.

Government of China. 2011b. The 588th Order of the State Council of the People's Republic of China. Beijing: Government of China. http://www.gov.cn/zwgk/2011-01/17/content_1785957.htm.

Information Office of the State Council. 2011. The White Book of China's Foreign Aid. Beijing: Information Office of the State Council. http://www.gov.cn/gzdt/2011-04/21/content_1849712.htm.

Leung, D., Zhao, Y., Ballesteros, A., and T. Hu. 2013. Environmental and Social Policies in Overseas Investments: Progress and Challenges in China. Beijing: World Resources Institute. http://pdf.wri.org/environmental_and_social_policies_in_overseas_investments_c hina.pdf.

Li, J., Newenham-Kahindi, A., Shapiro, D.M., and V.Z. Chen. 2013. "The Two-Tier Bargaining Model Revisited: Theory and Evidence from China's Natural Resource Investments in Africa." Global Strategy Journal 3(4): 300-321. 
Luo., Y., Xue, Q., and B. Han. 2010. "How Emerging Market Governments Promote Outward FDI: Experience from China." Journal of World Business 45(1): 68-79.

Ministry of Finance, and MOFCOM. 2012. Announcement for Application for 2012

Special Fund of International Economic and Technological Cooperation. Beijing: Ministry of Finance and MOFCOM. http://www.mofcom.gov.cn/aarticle/cwgongzuo/huiyj1/201207/20120708225224. html.

MOFCOM. 2009. Administrative Measures for Overseas Investment [MOFCOM 2009 No. 5 Order]. Beijing: MOFCOM. http://hzs.mofcom.gov.cn/aarticle/zcfb/b/200905/20090506252047.html.

MOFCOM. 2011. An Interpretation of the 'Work Safety Regulations on Chinese-Invested Enterprises and Organizations Overseas'. Beijing: MOFCOM. http://www.mofcom.gov.cn/aarticle/zhengcejd/bq/bv/201103/20110307466479.ht $\mathrm{ml} /$.

MOFCOM. 2012a. "A Brief Statistical Report of 2011 Chinese Non-Financial Outward Foreign Direct Investment.” MOFCOM News, January 19. http://hzs.mofcom.gov.cn/aarticle/date/201201/20120107934191.html.

MOFCOM. 2012b. 2011 Statistical Bulletin of China's Outward Foreign Direct Investment. Beijing: China Statistics Press.

MOFCOM. 2012c. MOFCOM, International Communication Office of the Communist Party of China's Central Committee, Ministry of Foreign Affairs, NDRC, SASAC, National Bureau of Corruption Prevention of China, All-China Federation of Industry and Commerce on the Release of the Opinions on Corporate Culture Construction of Chinese Enterprises Overseas. Beijing: MOFCOM. http://hzs.mofcom.gov.cn/aarticle/zcfb/b/201205/20120508126401.html.

MOFCOM. 2012d. Releasing of the '2012 Guidebook of Countries and Industries for Investment Overseas'. Beijing: MOFCOM. http://video.mofcom.gov.cn/exhibition/20121223/3177.html.

MOFCOM. 2013a. The Regulation of Behavior in Competition Abroad in the Area of International Investment and Cooperation. Beijing: MOFCOM. http://www.gov.cn/jrzg/2013-03/22/content_2360390.htm.

MOFCOM. 2013b. Global Investment and Cooperation Information Service System. Beijing: MOFCOM. http://femhzs.mofcom.gov.cn/fecpmvc/pages/fem/LoginedHome.html.

MOFCOM, and Ministry of Environmental Protection. 2013. Guidelines for Environmental Protection in Foreign Investment and Cooperation. Beijing: MOFCOM and Ministry of Environmental Protection. http://english.mofcom.gov.cn/article/policyrelease/bbb/201303/20130300043226. shtml.

MOFCOM, and Ministry of Forestry. 2009. Guidebook of Sustainable Operations and Exploration of Overseas Forests by Chinese Enterprises. Beijing: MOFCOM and Ministry of Forestry. http://www.gov.cn/gzdt/2009-06/01/content_1329230.htm. 
MOFCOM, and SAFE. 2009. Interim Measures for Joint Annual Inspection of Overseas Investment. Beijing: MOFCOM and SAFE. http://fec.mofcom.gov.cn/article/zcfg/zcfb/dwtz/200912/960806_1.html.

MOFCOM, Chinese Academy for Environmental Planning of the Ministry of Environmental Protection, and the Global Environmental Institute. 2010. Environmental Protection Policies on Chinese Investment Overseas. Beijing: MOFCOM, Chinese Academy for Environmental Planning of the Ministry of Environmental Protection, and the Global Environmental Institute. http://www.zhb.gov.cn/zhxx/hjyw/201007/t20100709_191903.htm.

NDRC. 2001. The 10th Five-Year Plan on Inward and Outward FDI. Beijing: NDRC. http://wwwold.sdpc.gov.cn/a/news/0112241.htm.

NDRC. 2004. Interim Administrative Measures for Approving Investment Projects Overseas [NDRC 2004 No. 21 Order]. Beijing: NDRC. http://www.ndrc.gov.cn/wzly/zcfg/wzzcjwtz/t20050719_37411.htm.

NDRC. 2007. MOFCOM, Ministry of Foreign Affairs and NDRC on Releasing the Third Edition of Guidance Catalogue on Outward Investment Industries. Beijing: NDRC. http://www.sdpc.gov.cn/zcfb/zcfbtz/2007tongzhi/t20070227_118707.htm.

NDRC. 2009. No. [2009]1479 Circular on Improving the Administrative Measures of Overseas Investment Projects. Beijing: NDRC. http://www.sdpc.gov.cn/zcfb/zcfbtz/2009tz/t20090619_286696.htm.

NDRC. 2011. No. [2011]235 Circular on Decentralizing the Approval Process of Overseas Investment Projects. Beijing: NDRC. http://www.ndrc.gov.cn/zcfb/zcfbtz/2011tz/t20110318_399946.htm.

NDRC. 2012a. The $12^{\text {th }}$ Five-Year Plan on Inward and Outward FDI. Beijing: NDRC. http://www.ndrc.gov.cn/gzdt/t20120724_493176.htm.

NDRC. 2012b. Exposure Draft (for Consultancy and Comments) of Approval Measures for Investment Projects Overseas. Beijing: NDRC. http://www.sdpc.gov.cn/tztg/W020120816523628797565.pdf.

NDRC. 2012c. Implementation Opinions on Encouraging and Guiding Private Enterprises to Engage in Investment Overseas. Beijing: NDRC. http://wzs.ndrc.gov.cn/zcfg/jwtzp/W020120703632702135836.pdf.

NDRC, and EXIM. 2003. Prority OFDI Projects for Credit Support [NDRC 2003 No. 226 Order]. Beijing: NDRC and EXIM. http://law.people.com.cn/showdetail.action?id=2654293.

NDRC, and EXIM. 2004. Priority OFDI Projects for Credit Support (Adjusted) [NDRC 2004 No. 2345 Order]. Beijing: NDRC and EXIM. http://wwwold.sdpc.gov.cn/b/b200411011.htm.

NDRC, MOFCOM, and Taiwan Affairs Office of the State Council. 2010. Administrative Measures for Mainland Enterprises Investing in Taiwan. Beijing: NDRC, MOFCOM, and Taiwan Affairs Office of the State Council. http://fec.mofcom.gov.cn/article/zcfg/zcfb/dwtz/201011/978651_1.html.

NDRC, MOFCOM, Ministry of Finance, Ministry of Science and Technology, Ministry of Industry and Information Technology, People's Bank of China, and General Administration of Customs. 2012. Guideline for Accelerating the Promotion of 
International Cooperation and New Competitive Advantages. Beijing: NDRC et al. http://wzs.ndrc.gov.cn/zcfg/zhp/t20120625_487154.htm.

NDRC, MOFCOM, Ministry of Foreign Affairs, Ministry of Finance, General Administration of Customs of the Peoples' Republic of China, and SAFE. 2006. Outward Investment Sector Direction Policy. Beijing: NDRC et al. http://tradeinservices.mofcom.gov.cn/b/2006-07-05/35669.shtml.

NPC. 2001. The $10^{\text {th }}$ Five-Year Plan on Economic and Social Development. Beijing: NPC. http://www.people.com.cn/GB/shizheng/16/20010318/419582.html.

PBC. 1990. The Administrative Measures of Financial Enterprises Overseas. Beijing: PBC. http://www.pbc.gov.cn/image_public/UserFiles/chubanwu/upload/File/\%E5\%A2 $\% 83 \%$ E5\%A4\%96\%Е9\%87\%91\%Е8\%9E\%8D\%Е6\%9C\%BA\%Е6\%9E\%84\%Е 7\%AE\%A1\%E7\%90\%86\%E5\%8A\%9E\%E6\%B3\%95.doc.

PBC. 2011. Interim Administrative Measures on Investment Overseas Settlement Accounts in Renminbi [PBC 2011 No. 1 Order]. Beijing: PBC. http://fec.mofcom.gov.cn/article/zcfg/zcfb/dwtz/201101/1185674_1.html.

SAFE. 2009. Foreign Exchange Administrative Regulations for Domestic Institutions Investing Abroad [SAFE 2009 No. 30 Order]. Beijing: SAFE. http://www.gov.cn/zwgk/2009-07/15/content_1366267.htm.

SAFE. 2012. Circular on the Foreign Exchange Administration Issues of Encouraging and Promoting Healthy Development of Private Investment. Beijing: SAFE. http://www.safe.gov.cn/wps/portal/!ut/p/c5/04_SB8K8xLLM9MSSzPy8xBz9CP0 os3gPZxdnX293QwML7zALA09P02Bnr1BvIyNvc6B8pFm8s7ujh4m5j4GBhY m7gYGniZO_n4dzoKGBpzEB3eEg-_DrB8kb4ACOBvpHvm5qfoFuREGWSaOigDuOwR_/d13/d3/L2dJQSEvUUt3QS9ZQnZ3LzZfSEN EQ01LRzEwODRJQzBJSUpRRUpKSDEySTI!/?WCM_GLOBAL_CONTEXT= /wps/wcm/connect/safe_web_store/safe_web/zcfg/zbxmwhgl/zjtzwhgl/node_zcfg _zbxm_kjtz_store/815d5c804b9fa26fa452bc53b1488d08.

SASAC. 2012. Interim Supervision Measures on SOE Investment Overseas [SASAC 2012 No. 28 Order]. Beijing: SASAC.

http://www.sasac.gov.cn/n1180/n1566/n258237/n258899/14404719.html.

SAT. 2007. Opinions on the State Administration of Taxation on Doing Well in the Taxation Service and Management for the Overseas Investments of Chinese Enterprises [SAT 2007 No. 32 Order]. Beijing: SAT. http://www.chinatax.gov.cn/n8136506/n8136563/n8193451/n8193481/n8193947/ 8240722.html.

SAT. 2010. Operation Guide on the Deduction and Exemption of Corporate Income Overseas [SAT 2010 No. 1 Order]. Beijing: SAT. http://www.chinatax.gov.cn/n8136506/n8136593/n8137537/n8138502/9786955.h tml.

SAT. 2011. Circular on the Reduction and Exemption of Revenues from Oil and Gas Extraction Projects Overseas by Chinese Enterprises [SAT 2011 No. 23 Order]. Beijing: SAT. 
http://www.chinatax.gov.cn/n8136506/n8136563/n8193451/n10623349/n106233 55/11718596.html.

Sauvant, K.P., and H. Chen. 2012. "A China-US Bilateral Investment Treaty: a Template for a Multilateral Framework for Investment." Columbia FDI Perspectives 85 (17 December). http://www.vcc.columbia.edu/content/china-us-bilateral-investmenttreaty-template-multilateral-framework-investment.

Sauvant, K.P., and F. Ortino. 2013. Improving the International Investment Law and Policy Regime: Options for the Future. Mimeo.

Sauvant, K.P., Sachs, L.E., and W.P.F.S. Schmit Jongbloed, eds. 2012. Sovereign Investment: Concerns and Policy Reactions. New York, US: Oxford University Press.

Sauvant, K.P., Economou, P., Gal, K., Lim, S., and W.P. Wilinski. Forthcoming. "Trends in FDI, Home Country Measures and Competitive Neutrality." In Yearbook on International Investment Law and Policy 2012-2013, edited by Andrea Bjorklund, ch. 1. New York, US: Oxford University Press.

SME IMDF. 2012. Administrative Measures for SME International Market Fund.

Beijing: SME IMDF. http://www.smeimdf.org/news/view.jsp?id=256190.

State Council. 2006. Opinions on Encouraging and Guiding Foreign Investment and Cooperation by Chinese Enterprises. Beijing: State Council. http://www.gov.cn/ldhd/2006-10/25/content_423660.htm.

State Council. 2011. (2011-2015) $12^{\text {th }}$ Five-Year Plan on Industrial Reform and Upgrading. Beijing: State Council. http://www.gov.cn/zwgk/201201/18/content_2047619.htm.

State Forestry Administration. 2010. A Guide on Sustainable Overseas Forests Management and Utilization by Chinese Enterprises. Beijing: State Forestry Administration. http://www.forestry.gov.cn/portal/main/s/224/content401396.html.

Sun, W., and B. Jiang. 2011. "How Chinese Investors 'Go Out'? Approval Processes at Home.” Peking University Law Literature. Accessed October 23, 2013. http://article.chinalawinfo.com/Article_Detail.asp?ArticleId=64555.

UNCTAD. 2013a. World Investment Report 2013. Geneva, Switzerland: UNCTAD. http://unctad.org/en/PublicationsLibrary/wir2013_en.pdf.

UNCTAD. 2013b. Total Number of Bilateral Investment Agreements Concluded [with China], 1 June 2013. Geneva, Switzerland: UNCTAD. http://unctad.org/Sections/dite_pcbb/docs/bits_china.pdf.

UNCTAD. 2013c. Country-Specific Lists of Bilateral Investment Treaties (1 June 2013). Geneva, Switzerland: UNCTAD. http://unctad.org/en/Pages/DIAE/International\%20Investment\%20Agreements\%2 0(IIA)/Country-specific-Lists-of-BITs.aspx?Do=151,50.

Wolff, L-C. 2011. "Chinese Investments Overseas: Onshore Rules and Offshore Risks." The International Lawyer 45(4): 1029. 
Yu, X., and L. Jiao. 2011. "A Brief Introduction of the 'Go Out' Strategy.” Qiaowu Gongzuo Yanjiu. Accessed October 23, 2013.

http://qwgzyj.gqb.gov.cn/yjytt/159/1743.shtml.

Zhang, J. 2011. "Chinese Foreign Economic and Trade Cooperation Zones:

Experimentation Field for Going Out of Chinese Enterprises." Xinhuanet.

Accessed October 23, 2013. http://news.xinhuanet.com/fortune/201110/22/c_111114998.htm. 